\title{
HYBRID WARFARE CHALLENGES ${ }^{1}$
}

\author{
Josipa Vuković \\ Dario Matika ${ }^{3}$ \\ Slavko Barić ${ }^{4}$
}

\begin{abstract}
In this article, hybrid warfare challenges and their impact on the evolution of warfare in the new dynamic security environment are analysed. The aim of the research was to identify hybrid threats, explore the complexity of the hybrid conflict that involves professional Armed Forces and irregular (paramilitary) forces. The research has been conducted through two case studies of hybrid warfare: the Israeli - Lebanese conflict in 2006 and the Lebanese militia organisation Hezbollah as a prototype of hybrid opponents; and the contemporary hybrid conflict in Ukraine through the Russian paradigm of hybrid warfare. The conducted research showed that the decisive role that influenced the outcome of the conflict belonged either to rapidness or inertia in of the making of political decisions. The research results showed further that revision of the existing strategic and doctrinal documents are required, as well as reorganisation of the national security system (and the Armed Forces as part of it), without which they will not be able to deal successfully with the dynamic nature of future conflict and complexity of threats ("synergy of threats"). The political decision is the most essential parameter for sizing military organisation. The rapidity of response in the event of emergencies (especially outside the national territory) also depends on the promptness of political decisions in order to activate the Armed Forces.
\end{abstract}

1 Statements and opinions expressed in the article are exclusively authors' and do not represent the views of the institutions where authors are employed.

2 Ministry of Defense, Trg kralja Petra Krešimira IV br. 1, 10000 Zagreb (josipa.vukovic@ gmail.com).

3 Croatian Defense Academy “Dr. Franjo Tuđman”, Ilica 256b, 10000 Zagreb (dario. matika1@gmail.com).

4 Croatian Defense Academy “Dr. Franjo Tuđman”, Ilica 256b, 10000 Zagreb (sbaric957@ gmail.com). 
Keywords: Hybrid threats, hybrid warfare, strategic documents, military doctrine, Armed Forces

\section{Introduction}

"The synergy of threats" has resulted in the emergence of hybrid warfare - a form of conflict in which regular and irregular military forces are involved together in order to achieve the same strategic objective. Although the hybrid mode of warfare has always been present in human history, it is the technological development of mankind that has led to more and more frequent use of this method of warfare. The very nature of war has not changed, as Clausewitz in his most general definition of war states: "War is just an extension of politics by other means" (Clausewitz, 1997, p. 63); war is still used to achieve political goals; however, the way funds are used to achieve these goals has changed, as well as the theatre of war, the battlefield and the techniques, tactics and procedures of war. Although many contemporary authors and analysts believe there will not be classic conventional conflicts any more, this is not the end of traditional warfare; on the contrary, future conflicts will be a combination of several different types of warfare.

The evolution of warfare presents the greatest challenge to a military organisation, because it affects the orientation of the armed forces within the omnipresent task of adjusting to the new dynamic security environment. However, a political decision plays the most important role in this case because the armed forces alone do not have the power to change the military doctrine and long-term development plans, which provide them with focus for training and adoption of new operational techniques and tactics of warfare.

The focus of this article is on the challenges of hybrid warfare, that is, it examines how changes in the international strategic environment influence the development of new security strategies and indirectly on the change of the character and manner of waging modern wars. The objective of this study was to identify hybrid threats, explore the complexity of hybrid conflict that includes both professional armed forces and irregular, paramilitary forces. Furthermore, the goal was to explore the way in which modern military organisations adapt and transform their skills to cope with the challenges of hybrid threats. 
Study results confirmed the hypothesis that changes in the international strategic environment together with the complexity of security threats lead to frequent occurrence of hybrid conflict. In order for countries to successfully cope with the challenges of "synergy of threats", a more complex cooperation of all the elements of the international community and the formation of new national security and defence policies are needed, which will then guide military organisations in the development of appropriate skills. The example of the transformation of NATO reveals that this organisation, motivated by complex threats and challenges, has already started adapting its concepts. The phenomenon of "synergy of threats" that results in a hybrid mode of warfare caused the flexible and rapid response through the mechanisms of crisis management which led to the formation of forces of rapid deployment in the area of operation and a high degree of mutual cooperation within the Alliance and with non-member states and other international organisations.

The new concept of NATO is already significantly affecting the adaptation of military doctrine of all Member States, their organisation, training and education, equipping, and the development of new capabilities of their armed forces. Revision of the current situation, restructuring of the national security system (and of the armed forces within it) and key documents have become a necessity if the armed forces want to successfully deal with the dynamic nature of future conflicts and complexity of threats. The impact of political decisions is the most crucial parameter for sizing and designing of military organisation, and the speed of response of the armed forces in the event of a crisis situation or threat depends directly on the political decision to be activated.

\section{Adaptation of NATO to the challenges of hybrid warfare and modus operandi}

NATO has had to adapt to the new security environment through the transformation of its structure and its strong defence policy. Robert Mikac says that in the area of response to the new security challenges, "transformation of the Alliance can be viewed through three broad categories: (1) the adoption of new strategic documents, (2) transformation of capacity and capabilities of the Alliance, 
and (3) development of partnerships with non-NATO countries" (Tatalović, Mikac, 2008, p. 72). The first changes and signs of transformation of the Alliance from its mission of collective defence into a mission of collective security are contained in the Strategic Concept adopted in Rome in 1991, in which security and stability do not depend any more on the military component of the Alliance only, but also on the political one, whose mechanisms the Alliance must further strengthen. The 2002 Prague Summit, where the creation of a rapid response force (NATO Response Force, NRF) was agreed on, is considered the next milestone in the transformation process. The NRF is a trained and technologically advanced multinational force made up of land, air and maritime components as well as special operations components that the Alliance can deploy quickly in the area where it is needed. In addition to its operational role, the NRF demonstrates operational readiness and acts as a test for the transformation of the Alliance. It is a means of the NATO Connected Forces Initiative (CFI) for better mutual cooperation, education and training and the implementation of a large number of joint exercises (NATO, 2015). In the words of General James Jones, former Supreme Allied Commander for Europe, "... NATO will no longer have large, massive troops that were needed during the Cold War, it will have agile and capable forces with a high level of readiness, which will better prepare the Alliance for meeting the likely threats of the $21^{\text {st }}$ century" (NATO, 2015).

One of the most important documents of the Alliance containing the guidelines for operation in the next decade is The Strategic Concept for the Defense and Security of the North Atlantic Treaty Organization Nations (2010) that was adopted at the Lisbon Summit in 2010. The Alliance, in order to ensure safety in the modern security environment that contains " $a$ broad and evolving set of challenges to the security of NATO territory and population", must meet three basic and key tasks (2010, para. 4): collective defence, crisis management and cooperative security. These tasks primarily involve the activation of the Alliance in accordance with Article 5 of the Washington Treaty, which includes defence "from any threat of aggression and from emerging security challenges threatening the fundamental security of individual Allies or the Alliance as a whole." For the Alliance to successfully participate in providing international security, it will continue to build a safe environment beyond its borders "through partnerships with relevant countries and other international organizations; active participation in the arms control, non-proliferation and disarmament; and leaving the door open for all European democracies that have 
achieved NATO standards to become members of the Alliance". In the chapter on security environment (2010, para. 7 to 15), it is stated that in the Euro-Atlantic security space, there is a small possibility of conventional attack although "conventional threat cannot be ignored" and threats to the security of citizens of the Alliance countries and international stability are cited.

The next significant adjustment of the Alliance was seen at the last NATO Summit held in Wales in 2014, at the time of the escalation of the Ukraine crisis, the outbreak of violence, terrorism and extremism of the self-proclaimed caliphate of the Islamic State in Iraq and Syria, the unrest in Libya, the Middle East and North Africa, etc. The main topics of the summit were the readiness of the Alliance for the strengthening of collective defence, development of the Alliance's own capabilities in order for it to be ready and interoperable to face the today's challenges, harmonisation of defence expenditures and obligations of member states to the Alliance, relations with Russia and Ukraine and the completion of the ISAF Operation in Afghanistan. Among the important guidelines of the Wales Summit, we must emphasise the adoption of the Readiness Action Plan (RAP) that will improve the Alliance's speed of response and produce a coherent and comprehensive package of measures for the challenges of the new security environment. RAP will "respond to the challenges posed by Russia and their strategic implications. It also responds to the risks and threats that arise from our southern neighbors, the Middle East and North Africa. The plan strengthens the NATO collective defense and also our ability for Crisis Management" (The Wales Summit Declaration, 2014, para. 5). The use of RAP is manifested through enhancement of NRF capabilities by increasing components and developing measures for very quick response to potential threats through deployment of a large number of multinational forces in the periphery of the Alliance. According to the Wales Declaration (2014, para. 8), the new Very High Readiness Joint Task Forces (VJTF) will basically consist of land components and will have at their disposal the appropriate component of air, sea and special forces. For VJTF to be ready to defend the territory of the Alliance and deploy within 48 hours into the area of operation, it is necessary to prepare the infrastructure (land and naval bases), enhance the capacity of conducting military exercises and establish the elements of command and control and component rotation on the eastern border. 
The conclusions of the Summit also addressed the emergence of new types of threats and the challenges of hybrid warfare as well as the question of whether and how NATO is ready to effectively respond to the "specific challenges of hybrid threats, which include an integrated full range of open and covert military, paramilitary and civilian activities" (2014, par. 13). The answer involves strengthening strategic communication, development of joint exercises with scenarios for suppressing hybrid threats, strengthening coordination between the Alliance and other organisations with the objective of exchanging information and political consultations, simply because modern technology will further increase the possibilities of unconventional opponents and allow them effective use of cyber-attacks, electronic warfare and the use of intelligence tools that will, if not prevented on time, have far-reaching consequences for the security of the Alliance. Such action or modus operandi is nothing but a hybrid mode of warfare that shapes the current security environment. Therefore, it is important to reexamine and analyse the lessons learned on examples of hybrid warfare through two case studies of hybrid warfare: the Israeli - Lebanese conflict in 2006 and the Lebanese paramilitary organisation Hezbollah as a prototype of a hybrid offence; and the contemporary hybrid conflict in Ukraine through the Russian paradigm of hybrid warfare.

\section{Hybrid segment of the Israeli - Lebanese war of 2006}

Hezbollah during the war with Israel in the summer of 2006 is cited as an example of a prototype hybrid organisation. In this conflict, Hezbollah demonstrated how the synergy of different methods of warfare successfully multiplied its advantage over its opponent, declared as the most powerful armed forces of the Middle East. To understand the hybrid context, it is necessary to examine the chronology of the conflict and the strategic context of the situation, that is, the presence of factors of the theory and principles of hybrid warfare. 


\section{Chronology of the conflict and strategic context}

The Second Israeli - Lebanese war of 2006 lasted a total of 34 days. On the one hand, it involved the strong conventional military power of Israel and, on the other, a combination of conventional and unconventional military forces of the Lebanese non-state actor, namely Hezbollah (McCulloh and Johnson, 2013, p. 19). The conflict began on 12 July 2006 wih Hezbollah's attack on Israeli border security forces, which resulted in the killing of three and the kidnapping of two Israeli soldiers. According to Murray and Mansoor (2012, pp. 14-16), Israeli Prime Minister Ehud Olmert gave the approval to the armed forces to launch an offensive operation on Hezbollah targets in southern Lebanon in order to deal with the frequent rocket attacks by Hezbollah from the said areas. Although this attack was nominally focused on Hezbollah, the State of Lebanon, whose government formally distanced itself from the actions of Hezbollah, was also indirectly attacked. Israel first responded with a failed attempt to rescue its soldiers and then conducted synchronised air and ground attacks on major infrastructure facilities together with a naval blockade of Lebanon's ports on the Mediterranean Sea. Hezbollah responded by launching hundreds of rockets on northern Israel and attacks with anti-ship missile C-802 on the INS Hanit, the Israeli Navy corvette which was implementing a sea blockade of Lebanon's ports. This was followed by daily rocket attacks from both sides towards goals on the opposite side. Israel hit targets with rockets using banned chemical weapons, namely bombs with white phosphorous, while Hezbollah used the tactics of guerrilla and powerful information war. In the first two weeks of the war, Hezbollah fired 2,200 rockets at targets in Israel, and the Israeli Air Force responded fiercely with rocket attacks on civilian targets in Beirut.

Attacks and fighting continued until August 11, 2006, when the armed forces of Israel (Israel Defense Force, IDF) with 30,000 soldiers tried to break into south Lebanon by launching operation "Operational direction change 11", which consisted of three venues of attack: the first was the northern sector, the second the central and western sector, and the third was called a battle to cross the strategic high ground Wadi Saluki that would ensure IDF control of the river Litani and penetration into the western areas of southern Lebanon. All battles ended with IDF halting their attack and highlighted the lack of "clarity of political decisions" 
and "command and control system" in IDF, which caused great losses (Katz, 2006). IDF's big losses and strong regional and international pressure together with mediation by the United Nations led to a ceasefire and the passing of UN Security Council Resolution No. 1701. It is interesting to point out that, in the end, both sides claimed victory in the war.

According to Matthews (2008), the war eventually ended with 1,200 casualties and more than a million displaced people in the area of southern Lebanon and northern Israel. 114 soldiers were killed on the Israeli side and a significant amount of Israeli military equipment was damaged or destroyed, including $10 \%$ of regular tanks, some helicopters and ships. More than 40 civilians were killed and around 4,000 were hurt or wounded. It is estimated that Israel suffered about 3.5 billion US dollars in losses through the cost of the war and in the economy. On the Lebanese side, Hezbollah lost 600 fighters, and it is estimated that their military capacity was reduced by $50 \%$. In addition, more than 1,000 Lebanese civilians were killed and more than 4,000 were injured. The damages in the devastated infrastructure were estimated to about 4 billion US dollars.

Hoffman (2007, p. 39) says that during the 34-day conflict, Hezbollah fired nearly 4,100 rockets. Although most of the missiles were short-range and inaccurate, they produced the strategic effect and forced a large number of the inhabitants of northern Israel to evacuate. Rocket attacks also had a psychological effect on Israel, because it was after the conflict that Israel started developing and building its system of air defence called Iron Dome. IDF performed almost 19,000 flights, dropping nearly 20,000 bombs and 2,000 missiles on almost 7,000 targets, and fired almost 125,000 artillery and heavy mortar shells.

According to McCulloh and Johnson (2013, pp. 20-21), in evaluating the strategic concept of the war, a strong historical, political, religious and ethnic context and the ensuing tensions between Israel and Hezbollah, should be considered. On the one side, we have Israel as a strong Jewish state, which has been fighting for survival in the Middle East throughout history and has a strong internal economy and advanced defence industry; on the other side there is Lebanon, a weak multicultural country with a blend of Eastern and Western culture and religion, power-sharing between a number of Christian and Muslim religions, poor structure of government, weak Armed Forces (LAF) and poor management of defence policy. It is in this in-between space that Hezbollah has found an 
opportunity for their political and military actions as a Shiite paramilitary group backed by anti-Israeli allies. Hezbollah complemented its asymmetric capabilities of guerrilla warfare and the use of criminal and terrorist methods with a substantial conventional capability of using rocket, artillery, air-defence, anti-ship and antiarmour weapons.

\section{Hezbollah as a prototype of a hybrid opponent}

The actions of Hezbollah in the Israeli - Lebanese war of 2006 perfectly demonstrates the theory, confirming the importance and synergy of hybrid warfare factors in relation to a dominant opponent. This conflict has shown the ability of a non-state actor, who had studied and analysed the vulnerabilities of the conventional forces with superior military capabilities, to successfully implement hybrid warfare. McCulloh and Johnson (2013, p. 21-25) defined seven principles of hybrid warfare, which they apply in the analysis of the Israeli - Lebanese war of 2006:

1. Composition, abilities and actions of hybrid forces are unique with regard to the context of their origin.

2. All hybrid forces have their own unique ideology that creates its image among the population.

3. Hybrid forces always perceive an existential threat to their survival.

4. Superiority between opponents is possible in the hybrid conflict.

5. Hybrid forces include both conventional and unconventional components.

6. Hybrid forces strive to use defensive operations, and

7. Use of hybrid power generates the tactic of weakening of the opponent.

Lebanon, as already mentioned, is a weak central government, with divisions and conflicts among ethnic groups. Therefore, Hezbollah as a Shiite militia in Lebanon enjoys great support from the Shiite population, which provides it with an unobstructed freedom of action and military development. The existence of specific ideology, inherent in an organisation that operates within a strategic arena, shapes the very identity of the forces. Hezbollah reflects the ideology of the righteous Islamic forces and identifies itself as an anti-Israeli force and as 
a protective Shiite militia, which enables its development and to claim the title of the dominant non-state actor in Lebanon.

Thus, hybrid forces as a non-state actor always perceive potential opponents as a threat and understand their advantages. This approach shapes their tactics and moves them away from the conventional approach, forcing them to use different methods of warfare to ensure their survival. In this case, Hezbollah perceived Israel as superior opponent and, according to Murray (2012, p. 290), IDF "burst" into Lebanon expecting to destroy their opponent quickly with their technology and conventional military superiority. But that did not happen because Hezbollah resorted to combining methods of warfare, i.e. to a hybrid manner of warfare. Hoffman (2007, p. 36) states that the war in southern Lebanon pointed to the weaknesses of conventional armed forces and says: "By mixing organized political movement with decentralized groups, which used the flexible tactics in uncontrolled areas, where Hezbollah proved that it was ready to inflict and experience defeat. Hezbollah possessed superior discipline, good training, distributed land battle groups and a will to fight against conventional enemy by using guerrilla tactics and technology in densely populated urban areas." Thus, the hybrid forces must find a way to overcome the conventional military advantage, that is, the ability to overcome the force of their superior opponent that has a developed military industry. Therefore, they organise themselves as an ad hoc militia, which depends on the illegal market of arms and financing by their allies who, to some extent, provide its basic equipment and weaponry. Innovation, flexibility and improvisation become powerful tools and are combined throughout the conflict. Due to the obvious asymmetry in the battlefield, hybrid forces, in order to ensure their advantage, are forced to combine conventional military technology with non-military guerrilla tactics of action.

Comparisons of capabilities and equipment of the armed forces show that the Israeli army had in its composition Sabra Mark I and Merkava Mark IV tanks, Namer armoured fighting vehicles, Golan Armoured infantry fighting vehicles , self-propelled artillery systems such as Lara and Sholef, and a number of different models of unmanned systems. In addition to this, its air component had Kfir fighters and F-16I as well as helicopters, and a number of various types of warships in the naval component. On the other side, Hezbollah depended on available resources during the conflict in the form of various types of anti- 
tank weapons, infantry weapons, anti-tank and anti-infantry mines, improvised explosive devices, short-range artillery weapons, air defence and anti-ship combat systems, and several types of rocket systems that it applied in a combination of conventional and guerrilla methods of warfare.

Furthermore, Hezbollah fought from previously prepared and fortified bunkers, which were distributed deeply in the territory of southern Lebanon. From these resistance points distributed over the depth of the territory, Hezbollah combatants carried out sudden attacks and followed the tactics "act and leave the position" further disorienting their opponent. This type of warfare is called the tactics of weakening and manifests itself in the physical and psychological domain that continuously reduces the combat power of the opposing forces. This was especially evident through the use of mines, improvised explosive devices, anti-tank rockets, indirect fire in combination with anti-armour and antiinfantry mines and infantry attacks from ambush, while at the very beginning of the conflict this was reflected in the kidnapping of two Israeli soldiers, followed by continuous bombing of civilian areas in Israel and very quick application of information warfare.

\section{The importance of information warfare}

One of the important factors of hybrid warfare is the information element, and the Israeli - Lebanese conflict in 2006 clearly shows the application of information management and media and their impact on the dynamics of the conflict. Fontana (2010, according to Kalb, 2007) points out that the media had never before transferred the raw reality of the battlefield in real-time: images of advancement of Israeli soldiers in southern Lebanon, the bombing of civilian houses and villages, civilians fleeing their homes, attacks on the airport in Beirut, Hezbollah's rocket attacks on Haifa, evacuation, bunkers, dead bodies etc. Thanks to the widely widespread technology, cameras, laptop computers and the Internet, formerly exclusively used by journalists, all of those images and stories became available to the general population in real time. Hezbollah heavily used the tactics of information warfare, taking advantage of their ownership of television broadcaster Al Manar ("resistance broadcast"), and many of the most important 
international media directly influenced public opinion and took sides during the conflict ${ }^{5}$. Hezbollah manipulated the publishing of information by having only one spokesperson and through strict surveillance of journalists in their area and encouraging them to feel free to require reports and photographs from $\mathrm{Al}$ Manara, thus indirectly shaping the opinion of the international community. On the other hand, the media closely followed the IDF's powerful counter-attacks on densely populated civilian areas in which Hezbollah operated and that caused a large number of civilian casualties and incalculable damage.

According to Mulhern (2012, p. 34), although at the start of the conflict Hezbollah did not have a developed diplomatic mission aimed specifically at prompting international pressure against Israel, it successfully provoked Israel to carry out actions that resulted in the destruction of its reputation in the international community and indirectly in the pressure to achieve a truce. How much Hezbollah was aware of the importance of information warfare can be seen by the twelfth of its thirteen principles of war that says "media have the power of countless gun, and their results strike like bullets" (Ya'ara according to Matthews, 2008, p. 7).

\section{Modern hybrid conflict in Ukraine}

The background of the conflict in the Crimea Peninsula and eastern Ukraine, that is the events that instigated separatist ideas and the rebellion of the pro-Russian population are the key to understanding the development of modern hybrid warfare that the Russian Federation conducted against Ukraine.

Encouraged by the technological development and the rapid development of the military industry, the Armed Forces of the Russian Federation, like other armies of the world, were forced to adapt their military doctrine and adopt new ways of war. According to Racz (2015, pp. 34-35), in his book, "If War Comes Tomorrow:

5 Fontana (2010: according to Kalb, 2007) states that the most important Arab television channels Al-Arabya and Al Jazeera portrayed Israel as an attacker. The BBC showed both as aggressors, although blaming Israel more. US media were divided: Fox News was on the side of Israel, CNN was trying to be neutral, and ABC, CBS and NBC channels were more critical of Israel than of Hezbollah. The New York Times and Washington Post represented Israel as the attacker twice as often as Hezbollah on their front pages. 
The Contours of Future Armed Conflict" published in 1998, Russian General Makhmut Gareev predicted that the technological development of information warfare will make warfare much more sophisticated. Computers and communications systems will allow fast access to information and a very short decision making time in the command and control system. In addition, he also presupposed the widespread use of electronic warfare with the aim of disrupting the functionality of enemy communications, radar systems and command and control system. As the objective of information warfare, Gereev said that systematic broadcasting of psychologically and ideologically biased materials through mixing truth and falsehood can lead to undermining confidence in the nation's government and armed forces, which will ultimately destabilise the country and create conditions for the opponent to attack.

In 2013, the current Chief of General Staff of the Russian Federation, Staff General Valery Gerasimov, referring to the experience of the Arab Spring, brought forth the idea of a new form of warfare that combines diplomatic, economic, political and other non-military methods with direct military force instead of conducting an open conflict, with greater emphasis on non-military means over the classical military ones. Even at that time, Gerasimov foresees asymmetric methods through paramilitary and civil rebel forces without the open use of force and stresses the importance of information space and coordination of actors in real time. He also highlights the choice of targets of sabotage inside the opponent's territory through the destruction of civilian infrastructure and high value military targets and the use of special forces and unmanned systems. He believes that regular forces should be included at a later stage of the conflict, possibly under the guise of peacekeeping forces or crisis management forces (Rácz, 2015, pp. 36-37). Although the strategy of the Russian hybrid warfare was presented to the public a few months before anti-government protests on the Maidan, it was put perfectly into practice during the operation to take over the Crimean Peninsula.

\section{Chronology and strategic context of the war}

After the collapse of the Soviet Union, on 24 August 1991, Ukraine declared its independence, which somehow defined today's multipolar Ukrainian society and left a mark on the permanent division into the pro-Russian and anti-Russian 
population on a national, cultural, religious, linguistic and political basis. The turning point in the security situation in Ukraine happened in November 2013 with the anti-government protests in Kiev at the Independence Square. Protests, known in Ukraine as the Revolution of Dignity, turned from politically motivated peaceful demonstrations into a quite radical protest. The reason for the protests was the bad foreign policy of the then President of Ukraine Viktor Yanukovich. The European Union and Ukraine had already launched the Association Agreement in March 2012, which was to be ratified after Ukraine had fulfilled all the conditions prescribed by the Agreement. The Russian Federation, determined to halt Ukrainian accession to the EU and in order to prevent Ukraine from signing a trade agreement with the European Union, imposed economic sanctions and stopped all imports of goods from Ukraine. Although European Union officials tried to save the signing of the agreement, in November 2013, at the Summit in Vilnius, President Yanukovych did not sign the Treaty of Accession to the European Union, with the aim of strengthening ties with the Russian Federation. President of the European Commission Jose Manuel Barroso said at the time that the EU "will not give in to the external pressure, especially not the Russian" although supporters of Ukraine joining the EU believed that the way to membership was also the path for pulling out from the chaos of corruption and political battles choking the country. The protests escalated in late February 2014, when the Ukrainian Parliament refused to reduce presidential powers and return the power to the Constitution of 2004. Ukraine has since found itself in a crisis which, in this already divided country, further deepened the rift in the population, dividing the citizens into proRussian and anti-Russian camps, or, in other words, citizens who wanted stronger ties with the West and Europe and citizens who wanted stronger ties with the East and Russia. In February 2014, pro-European Maidan protests escalated into the Ukrainian crisis. The change of government in Ukraine, which the Russia did not recognise, caused the Crimean Peninsula and the areas with a higher percentage of ethnic Russian population to experience further dissatisfaction and rebellion. In late February 2014, under the guise of fighting for equality and with the support of local authorities, unidentified armed groups began to take over important infrastructure sites and facilities of the Autonomous Republic of Crimea, and already the Russian Federation began to take control of the situation on the ground. That was when the conflict between the Russian Federation and Ukraine evolved from a political and economic conflict into a low-intensity conflict with the aim 
of taking control over the Crimean Peninsula. In the referendum on the status of Crimea, conducted on 16 March 2014, 97\% of the population voted for separation from Ukraine and annexation to Russia, and the Republic of Crimea was formed as an integral part of the territory of the Russian Federation. The focus of conflict then shifted northeast of Crimea, to the south-western borders of the Russian Federation, where a separatist pro-Russian rebellion very similar to that in the Crimea broke out. The armed conflict in eastern Ukraine was formally launched in early April 2014, after acting President of Ukraine, Oleksandr Turchynov, decided to conduct counterterrorism operations and regain control of the area occupied by the Donbas terrorists. In the meantime, the self-proclamation of the so-called "Donetsk People's Republic" and "Lugano People's Republic", two unrecognised separatist entities, was implemented.

The Ukrainian crisis was accompanied by intense, well-coordinated diplomatic, economic and media campaigns both in Ukraine and abroad. These actions were further supported by the pressure of Russian military troops deployed along the border with Ukraine. Highly trained and well-equipped separatist forces, together with their local allies, were able to completely disable the functioning of the Ukrainian state administration in the Crimea, which resulted in the rapid annexation of the Peninsula by the Russian Federation, almost without firing a shot at civilians. According to András Rácz (2015, pp. 11-14), a Finnish expert on post-Soviet security policy, the most effective separatist forces consisted of superbly trained, well-equipped "little green men", given the tactics that were used in the conflict and the fact that technology, equipment and weapons used in the conflict were exclusively of Russian origin.

The intensive development of the Crimean crisis shocked both the newly established Ukrainian government and the Western world. The very effectively coordinated actions of Russian troops, pro-Russian oriented local separatists and the Russian media and diplomats, has been described by many military experts as a great example of a hybrid war (Rácz, 2015, p. 11).

6 Little green mеn (Rus. зелёные человечки, Ukr. зелені чоловічки) is a colloquialism in Ukraine for masked soldiers wearing green uniforms without any insignia or markings, but who are equipped with Russian weapons and military equipment. 


\section{The paradigm of Russian application of hybrid warfare in Ukraine}

Rácz (2015, pp. 57-67) analyses the operations which were conducted by the Russian Federation in Crimea and eastern Ukraine as having three main phases: preparation phase, attack phase and stabilisation phase. The analysis was conducted based on the events that took place in the field; however, the initial phase is missing, i.e. the phase of operational planning, which is probably the most closely guarded state secret. According to the article "Hybrid war in the near abroad" (Dorschner, March 11, 2015, p. 24-30) in Jane's Defense Weekly, the Russian form of hybrid warfare in Ukraine consists of four components: political subversion, securing safe havens, intervention and further intimidation. The paradigm was presented on March 10, 2015 at a conference of the Russian Military Forum (The Russian Military Forum: Russia's Hybrid War Campaign: Implications for Ukraine and Beyond) at the Center for Strategic and International Studies (Center for Strategic and International Studies - CSIS).

The Russian side had an advantage with respect to the common past and the interconnectedness of economic and social factors. Knowledge of how Ukraine functions and its advantages and disadvantages facilitated the preparatory phase. Through diplomatic activities and soft coercion through the media, the Russian Federation additionally strengthened its influence as well as the separatist tendencies of the targeted regions. Further destabilisation was purposefully triggered through already existing dissatisfaction among the local population with the functioning of the central government, by bribing local politicians and administration and financing of the actions of local criminal groups, all this with the objective of spreading ethnic, religious and social unrest. The preparatory phase, or the stage of political subversion, was concluded by mobilisation of the aforementioned means of influence and the implementation of coordinated actions in each segment. By linking these actions with additional mobilisation of the Armed Forces of the Russian Federation under the guise of implementing military exercises, favourable conditions for the continuation of hybrid warfare were created. Measures implemented at this stage did not include the open use of violence, that is, the line that would permit Ukraine to use countermeasures and protect its sovereignty had not been crossed. 
The crisis that broke out in a similar way both in Crimea and eastern Ukraine began by taking critical civil infrastructure ${ }^{7}$. During the attack phase, massive anti-government protests were organised, accompanied by general unrest and sabotages of the aforementioned facilities. Simultaneously with these actions, well-organised and armed demonstrators started to appear; although dressed in civilian clothes, they showed good tactical skills and began to occupy the television and radio towers, arguing that local protesters were dissatisfied with the central government in Kiev. Due to the established communication - information monopoly ${ }^{8}$ and the conducting of an intensive media campaign ${ }^{9}$, Kiev was totally disabled in its activities. The implementation of non-military operations led to the establishment of alternative governance bodies and new political bodies referring to the constant lack of understanding of the central government and separatist ideas and the final surrender of Crimea almost without firing a shot. Although the Armed Forces of the Russian Federation did not formally take part in the attack phase, their impact is visible both in the Crimea and in the east of the country, through the deployment of mechanised troops and heavy artillery along the state border with the aim of diverting the attention and resources of Kiev in the event of counter-attack. Ukraine has been brought to "stalemate" having been blocked by the direct threat of a strong conventional attack by the Russian Federation.

In order to consolidate the results of hybrid war, it is necessary to implement strategic and political stabilisation to additionally strengthen the legitimacy of the new government. In the beginning, the development of the situation in the Crimea and eastern Ukraine followed the same pattern: a referendum ${ }^{10}$ for independence

7 On February 27, 2014, in the Crimea, "little green men" first occupied the building of the Parliament to prevent the functioning of local authorities. The first building in Donetsk which was occupied in April 2014 was the building of regional state administration. The police and local security forces failed to defend the building, because they were not issued clear orders for its defence, because of their low morale, poor leadership and inadequate equipment.

8 Meanwhile, the media, under the influence of the attacker, spread disinformation and discredited the attacked country trying to disorient international politics by the level of falsehood. 9 An intensive media campaign successfully influenced the confusion of decision-makers, spreading fear and dissatisfaction with the central government and thereby weakening the potential and effective perception of the local Ukrainian army and police.

10 In the referendum in the Crimea on March 16, 2014, 97\% of the population of Crimea voted for annexation to Russia, and 3\% for the autonomous status of Crimea as part of Ukraine. On Apr 4, 2014, the activists who occupied the regional administration building in Donetsk proclaimed the People's Republic of Donetsk in the Donetsk area in Ukraine. On May 14, 2014, the People's Republic of Lugano in the Lugano area in the east of Ukraine was self-proclaimed, too. Both self-proclaimed entities have no legal democratic legitimacy. 
was organised in which, in both cases, separatists won the majority. However, in that moment, a difference in the scenario occurs: Crimea's annexation by the Russian Federation was over in practically one day and in the eastern Ukraine, pro-Russian separatism had not reached a sufficient level to be operationalised to the full extent. During the last phase of hybrid warfare, two outcomes were possible; the first, when the attacking country merges captured territory with its own (Crimea) or the second, when the occupied territory remains within the attacked country so that the attacker can use its presence there to further weaken the central government politically, economically and militarily (east Ukraine).

In this case, unlike the previous one, it can be seen how the military superiority of the attacking country over the attacked country is a condition for the successful implementation of hybrid warfare. The military superiority of the attackers was crucial in the implementation of the attack phase of hybrid warfare, in order to prevent the attacked country from undertaking armed resistance by a conventional attack against a much stronger opponent. Using the example of Crimea, we can see the impact of Russian Armed Forces deployed along the border with Ukraine officially only conducting military exercises ${ }^{11}$ in the area. The fear of direct confrontation with the Russian Federation acted as a deterrent and restricted the Ukrainian authorities' freedom of decision-making. And, finally, the big role given to information operations, special and electronic warfare led ultimately to the full achievement of the planned objectives and enabled the continuation with the conventional forms of warfare, and thus the realisation of the political intentions of the Russian Federation.

11 Russian President Putin commanded the maintenance of emergency military exercises across western and central Russia in the period from February 26 to March 3, 2014. At the same time, the Russian defence minister, Sergei Shoigu, said: "These exercises are not in any way related to the events in Ukraine". One part of the sudden military exercises, which was testing the readiness of the Russian military, took place on Russia's borders, too, including the border with Ukraine. In these large military exercises, a total of 150,000 troops, 90 military aircraft, over 120 helicopters, 880 tanks and 1,200 pieces of military equipment were engaged. (Tensions on Crimea, Feb 26, 2014). 


\section{Conclusion}

The research, based on the two study cases, confirmed the hypothesis that the hybrid way of warfare has a significant impact on the development of new capabilities of military organisation. Military organisations, in order to meet their basic tasks, are being forced to adapt to constant changes in the international strategic environment and the complexity of threats ("synergy of threats"), which together form a hybrid consisting of conventional and unconventional forms of warfare. Therefore, the future holds the unpredictability of events and new forms of combination of threats, specially adapted to successfully hinder vital values and test the quality of defence capabilities.

Rapid technological and economic development and informatisation of society have influenced the emergence of new threats giving them global extensibility and character. Now is the time when the conventional inter-state conflicts are likely to be replaced by hybrid wars and asymmetric battles in which a clear distinction between soldiers and civilians, between organised violence, terror, crime and war or a state of peace and war conditions disappears. Nonlinearity and complexity are a challenge for the process of making political and military decisions for the armed forces because it tests both their weaknesses and their capabilities. This requires rapid change of the existing tactics and techniques of warfare in order for the security and military organisations to timely respond to the challenges of the modern security environment.

It was therefore important to examine real cases of hybrid warfare and organisations that conducted it in order to achieve their goals (lessons learned). In the analysed cases of Lebanese Hezbollah and Ukrainian pro-Russian separatists, we can observe a combination of conventional and unconventional forms of warfare and quick adjustment of the components that achieved the desired political goals in a very short period of time with the help of sophisticated technology and tactics.

Given the relatively short duration of the conflict, conducted doctrine and obtained results, the research has clearly shown that, both in the case of the Israeli Government and the Ukrainian authorities, speed of action had the decisive and key role on the one side, and inertia in the political decision-making that affected the final outcome of the conflict in favour of hybrid opponents on the other. 
Therefore, as we pointed out in the introduction to this article, the revision of the current situation, restructuring of the national security system (and the armed forces as part of it) and key documents, is a necessity without which the armed forces will not be able to successfully deal with the dynamic nature of future conflict and the complexity of threats ("synergy of threats"). That is why it is important to emphasise that, in this context, "the influence of the political decision" is the most crucial parameter for the design of military organisation and that the speed of response of military forces in the event of a crisis or threat (especially outside the national territory) depends on the speed of political decisions to be activated, both at the national level and within the Alliance.

\section{Bibliography}

Clausewitz, Karl von (1997) On war. Zagreb: Ministry of Defense of the Republic of Croatia.

Dorschner, Jim „Hybrid war in the near abroad“, IHS Jane's Defence Weekly, March 11, 2015, Vol 52, Issue 10, pp. 24-30.

Hoffman, Frank (2007) Conflict in the 21 $1^{\text {st }}$ Century: The Rise of Hybrid Wars. Virginia: Potomac Institute for Policy Studies.

Katz, Yaakov article Wadi Saluki battle - microcosm of war's mistakes, published on August 29, 2006, online newspaper The Jerusalem Post, available at:

http://www.jpost.com/Israel/Wadi-Saluki-battle-microcosm-of-wars-mistakes, accessed on Oct 2, 2015,

Russian Military Forum Conference at the Center for Strategic and International Studies, Russia's Hybrid War Campaign: Implications for Ukraine and Beyond, available online at: https://www.youtube.com/watch?v=8WA1rP5WGfY.

Matthews, Matt (2008) We Were Caught Unprepared: The 2006 Hezbollah-Israeli War, Kansas: U.S. Army Combined Arms Center, Combat Studies Institute Press The Long War Series Occasional Paper 26.

McCullah, Timothy i Johnson, Richard (2013) Hybrid Warfare. Florida: Joint Special Operations University.

Mulhern, Stephen Keith (2012) Master of Science Thesis, An Analysis of Hezbollah's use of Irregular Warfare, Intelligence and National Security Studies Program, Texas: The University of Texas at El Paso.

Murray, Williamson and Mansoor, Peter R. (2012) Hybrid Warfare - Fighting Complex Opponents from the Ancient World to the Present. Cambridge University Press. 
Tensions in Crimea: conflict between pro- and anti-Russian demonstrators, Kiev militants threaten to come to Sebastopol, Putin ordered sudden large military exercises all over central and west Russia, including along Ukrainian border, author not signed, published on Feb 26, 2014, in the online newspaper advance.hr, available at: http:// www.advance.hr/vijesti/napeto-na-krimu-sukob-pro-i-anti-ruskih-prosvjednikamilitanti-iz-kijeva-prijete-dolaskom-u-sevastopolj-putin-naredio-iznenadnevelike-vojne-vjezbe-diljem-centralne-i-zapadne-rusije-ukljucujuci-i-uz-ukrajinskugranicu/

North Atlantic Treaty Organization, Official NATO web site, www.nato.int.

North Atlantic Treaty Organization, NATO Response Force, Official NATO web site, Rapid Response Force, http://www.nato.int/cps/en/natolive/topics_49755.htm.

Rácz, Andras (2015.) Russia's Hybrid War in Ukraine - Breaking the Enemy's Ability to Resist, FIIA Report 43. Helsinki: The Finnish Institute of International Affairs.

Strategic Concept for Defense and Security of the Members of the North Atlantic Treaty Organization (Lisabon 2010), available online at:

http://www.nato.hr/Media/Default/images/Strate\%C5\%A1ki\%20koncept\%20za\%20 obranu\%20i\%20sigurnost\%20\%C4\%8Dlanica\%20Organizacije\%20sjevernoatlan tskog\%20sporazuma.pdf.

Tatalović, Siniša ur. (2008.) Croatia and European Security Environment; Mikac, Robert NATO's Role in the Planning for Crisis Situations, pp. 70-86. Zagreb: Political Culture.

Wales Summit Declaration (2014) available online at: http://www.nato.int/cps/en/natohq/official_texts_112964.htm.

Vuković J., "Izazovi hibridnog ratovanja”, završni specijalistički rad, Fakultet političkih znanosti Zagreb, 2016. 